\title{
Tropical Pacific Ocean Dynamical Response to Short-Term Sulfate Aerosol Forcing
}

\author{
TARUN VERMA \\ Los Alamos National Laboratory, Los Alamos, New Mexico \\ R. SARAVANAN \\ Department of Atmospheric Sciences, Texas A\&M University, College Station, Texas \\ P. CHANG \\ Department of Atmospheric Sciences, and Department of Oceanography, Texas A\&M \\ University, College Station, Texas \\ S. MAHAJAN \\ Oak Ridge National Laboratory, Oak Ridge, Tennessee
}

(Manuscript received 17 January 2019, in final form 13 August 2019)

\begin{abstract}
The large-scale and long-term climate impacts of anthropogenic sulfate aerosols consist of Northern Hemisphere cooling and a southward shift of the tropical rain belt. On interannual time scales, however, the response to aerosols is localized with a sizable imprint on local ocean-atmosphere interaction. A large concentration of anthropogenic sulfates over Asia may impact ENSO by modifying processes and interactions that generate this coupled ocean-atmosphere variability. Here, we use climate model experiments with different degrees of ocean-atmosphere coupling to study the tropical Pacific response to an abrupt increase in anthropogenic sulfates. These include an atmospheric general circulation model (GCM) coupled to either a full-ocean GCM or a slab-ocean model, or simply forced by climatology of sea surface temperature. Comparing the responses helps differentiate between the fast atmospheric and slow ocean-mediated responses, and highlights the role of ocean-atmosphere coupling in the latter. We demonstrate the link between the Walker circulation and the equatorial Pacific upper-ocean dynamics in response to increased sulfate aerosols. The local surface cooling due to sulfate aerosols emitted over the Asian continent drives atmospheric subsidence over the equatorial west Pacific. The associated anomalous circulation imparts westerly momentum to the underlying Pacific Ocean, leading to an El Niño-like upper-ocean response and a transient warming of the east equatorial Pacific Ocean. The oceanic adjustment eventually contributes to its decay, giving rise to a damped oscillation of the tropical Pacific Ocean in response to abrupt anthropogenic sulfate aerosol forcing.
\end{abstract}

\section{Introduction}

An important consequence of anthropogenic climate change is the modification of tropical atmospheric circulation. Under greenhouse gas warming, the tropical circulations weaken (Held and Soden 2000; He and Soden 2015). Climate model studies show that the intertropical convergence zone (ITCZ) shifts southward in response to anthropogenic sulfate aerosol forcing (Rotstayn and Lohmann 2002; Shindell et al. 2012; Allen et al. 2015). These changes can cause droughts and

\footnotetext{
Corresponding author: Tarun Verma, tarunverma@lanl.gov
}

floods over the tropical landmasses (Nobre and Shukla 1996; Giannini et al. 2003; Biasutti and Giannini 2006) and can spur long-term climatological impacts across the tropics. This zonal mean displacement can be predicted based on simple energetics (Donohoe et al. 2013; Frierson et al. 2013; Schneider et al. 2014); the ITCZ shifts in order to compensate for the hemispheric excess or scarcity in energy caused by greater anthropogenic sulfate aerosol emissions over the Northern Hemisphere. On a regional scale, however, one needs to consider local factors like sea surface temperature (SST), lower-level circulation, and their interaction, which determine the extent of the ITCZ shift (Nobre 
and Shukla 1996; Chang et al. 1997; Xie 2004; Chiang and Vimont 2004). The real world, however, is inherently complex and cannot be simply explained by a single mechanism. Both the strength and the position of the ITCZ during the past century are jointly controlled by more than one forcing type and are strongly modulated by intrinsic climate variability (Chang et al. 2011; Hwang et al. 2013; Friedman et al. 2013; Green and Marshall 2017). The observed displacement during the twentieth century (Green et al. 2017; see Fig. 2) is, therefore, not fully understood.

The effect on zonally asymmetric circulation, namely, the Walker cell, is even less understood. The variability associated with El Niño-Southern Oscillation (ENSO) greatly reduces the signal-to-noise ratio on seasonal-tointerannual time scales. Additionally, the Walker circulation is inherently tied to the meridional cell, through the returning equatorward flow, which makes it conceptually difficult to separate the two. As a result, the twentieth-century changes in Walker cell and their causes are still unresolved problems and actively studied (Tokinaga et al. 2012; L'Heureux et al. 2013; McGregor et al. 2014; England et al. 2014). Like the meridional cell, the Walker cell weakens in the warming world, partly through the thermodynamical constraint proposed by Held and Soden (2000). The other contribution comes from the reduction in the tropical Pacific zonal SST gradients and changes in the ocean thermocline (Vecchi and Soden 2007; He and Soden 2015; Cai et al. 2015). The impact of aerosols on the Walker cell is unclear, but recent studies link weakening of the South Asian monsoon (and the Walker cell) since the 1950s to an increase in aerosols, particularly over Asia (Bollasina et al. 2011).

Others have also linked the Walker circulation strength to variations in the global mean surface temperature (Kosaka and Xie 2013; England et al. 2014). The twentieth-century global mean climate is characterized by a long-term warming trend that slows down and speeds up, intermittently. The increasing trend is typically attributed to the steady increase in well-mixed greenhouse gases. The short-term changes are either attributed to intrinsic climate variability or changes in short-lived radiative gases and aerosols. Their relative contribution to modulating the warming is uncertain as separating a robust response (to an external forcing) from the intrinsic noise is extremely challenging and is still actively debated. Some studies based on the observational record and climate model simulations (Swanson et al. 2009; DelSole et al. 2011; Wu et al. 2011) suggest that twentieth-century climate is primarily modulated on multidecadal time scales by processes internal to the climate system. Others (Smith et al. 2016;
Takahashi and Watanabe 2016) highlight the importance of aerosols in driving recent decadal to multidecadal variations. Fundamental to this ambiguity is the poor understanding of how aerosol radiative forcing interacts with natural modes of climate variability. We address the above limitation by carefully examining the potential interactions between the radiative effects of sulfate aerosols (or sulfates; IPCC 2013, and references therein; Ocko et al. 2014; Boucher 2015) and the dynamical processes that drive ENSO (Neelin et al. 1998; Wang and Picaut 2004; Dijkstra 2006).

The proximity of the tropical Pacific to East Asia, a major source region of industrial sulfates, makes it susceptible to variations in aerosol emissions; therefore, this is an important problem to study. This study differs from the previously mentioned studies in being focused entirely on the tropical Pacific region where there is significant intrinsic variability associated with ENSO on seasonal-to-interannual time scales, shorter than the decadal-to-multidecadal range. Additionally, instead of focusing on attribution, we ask the fundamental question: How does the tropical Pacific climate system, where ENSO is dominant, respond to an abrupt increase (from preindustrial to present-day level) in tropospheric sulfate aerosols on seasonal-to-interannual time scales? These time scales are often omitted in studies describing the climate response to aerosol forcing that make distinction between the fast (atmospheric; few days to a month) response and the slow (ocean-mediated; multidecadal) equilibrium response. In this study, we attempt to fill the gap between the two extremes by examining interactions between aerosols and relatively faster upper-ocean dynamics. The similarity between the radiative effects of tropospheric sulfate aerosols and those from volcanic sulfates makes this study relevant to decadal-scale climate response after a tropical volcanic eruption (Pohlmann et al. 2013; Maher et al. 2015; Timmreck et al. 2016).

After decades of research on the aerosol effect on climate, many aspects of its impacts are still unresolved (Stevens and Feingold 2009). According to the latest IPCC report (IPCC 2013), large error bars in the global anthropogenic radiative forcing result from uncertainty in quantifying aerosol related processes. The error bars in the radiative forcing (RF) in turn translate into an uncertain climate response to the aerosol forcing, especially on regional scales. An additional uncertainty in climate response can stem from the inability to fully account for various feedbacks. The effects of missing or inaccurate short-term feedbacks have already been accounted for in the RF uncertainty. On the other hand, the long-term feedbacks that are mediated through SST and/or upper-ocean changes are typically stronger and 
can have greater impact on the climate (IPCC 2013; Boucher 2015).

In spite of improvements in representation of basic processes in climate models, the role of ocean feedback is poorly understood, resulting sometimes in ambiguous climate response attribution to aerosols. For example, Booth et al. (2012) attribute twentieth-century North Atlantic decadal climate variability to aerosol effects whereas Zhang et al. (2013) argue against it. The major challenge in attributing twentieth-century regional climate change to an external forcing is the difficulty in removing the effects of internal climate variability, which are in turn tied to the ocean response. The importance of ocean mediation of climate response to aerosol changes is also regularly stressed in geoengineering (Ammann et al. 2010) and in studies of climate response to volcanic eruptions.

The effect of volcanic eruptions on tropical climate variability is an example of naturally occurring interaction between sulfate aerosols and the tropical Pacific. The large-scale surface cooling post-eruption is a robust climate response (Collins 2003); however, the regional effects are less well understood. Recent studies on decadal-scale predictability suggest that volcanic forcing can significantly affect forecast skill over the eastern tropical Pacific (Timmreck et al. 2016; Pohlmann et al. 2013). Others (Maher et al. 2015; Ohba et al. 2013) shows increased likelihood of El Niño 6-12 months after peak volcanic forcing. An inverse study by Lehner et al. (2016) also indicates that large-scale volcanic cooling is modulated by the phase of ENSO.

In contrast, the anthropogenic increase in sulfates since the preindustrial period has resulted in widespread cooling of the Northern Hemisphere (NH) where most emission sources are located. This hemispheric asymmetry leads to changes in meridional energy transports that shift the ITCZ southward and affect zonal mean tropical atmospheric circulation (Chiang and Friedman 2012; Schneider et al. 2014). These long-term or equilibrium climate responses are observed in nature (Green et al. 2017) and are to a large extent simulated (Williams et al. 2001; Hwang et al. 2013) by climate models. However, on shorter time and space scales, the response remains poorly understood and will be explored in this study.

Considering the notable zonal asymmetry in the tropical Pacific mean state (warm pool and cold tongue) and variability (seasonal cycle, El Niño-Southern Oscillation), it would be appropriate to ask the following questions: Does a zonally asymmetric aerosol perturbation (high sulfate concentrations over East Asia) project onto the zonally asymmetric mode of climate variability (McPhaden et al. 2006) or the zonally asymmetric tropical Pacific mean state? Does it impact the zonally asymmetric Walker circulation, which is closely tied to the South Asian monsoon? Does the regional response to sulfate aerosols differ substantially from the well-known large-scale and long-term response that could benefit predictions on seasonal to interannual time scales? What role does dynamical ocean-atmosphere coupling over the tropical Pacific play in the climate response to aerosols? To answer and explore these questions and ideas, section 2 explains model and experimental details followed by analysis and results in section 3. Finally, section 4 summarizes the results and discusses their implications.

\section{Method and model details}

We used the NCAR Community Earth System Model (CESM), version 1.1.2 (Hurrell et al. 2013), with either prescribed SST or prognostic SST through coupling with a full-ocean or a slab-ocean model. In each case, the sensitivity of the tropical Pacific climate is tested by abruptly increasing sulfates and its precursor gas emissions from preindustrial to present-day level [based on the Lamarque et al. (2010) emission inventory] and the difference in simulated ensemble mean climate between the two scenarios (preindustrial control and perturbed present-day sulfate) is examined.

To characterize the control climate, a 110-yr-long fully coupled control simulation with preindustrial settings, denoted $1850 \mathrm{~S}$, was carried out using the fully coupled CESM. An ensemble of 4-yr-long perturbed simulations, denoted 2000S, was created by starting integrations from every January in the control simulation with year-2000-level sulfate emissions. The emissions are monthly and spatially varying climatology of the sulfate aerosol and precursor $\mathrm{SO}_{2}$ whose chemical and physical transformation are accomplished online using a module named MAM3 (Liu et al. 2012). They are also allowed to interact with meteorology, radiation, and clouds resulting in nonuniform loading and the radiative perturbation that varies in space and has distinct annual or shorter time-scale variations. This approach is an effective way to study the transient tropical Pacific adjustment to the sulfate aerosol forcing. Figure 1 depicts how the Niño-3.4 index, a metric of ENSO variability, responds when sulfate concentrations in the atmosphere are abruptly increased for the initial 2 years. The apparent year-to-year divergence results from the stochastic and nonlinear nature of the climate and ENSO systems. Averaging over an ensemble of responses identifies the most probable response of the tropical Pacific climate system to increased aerosols. Additionally, limiting the perturbed simulations to a 4-yr period 

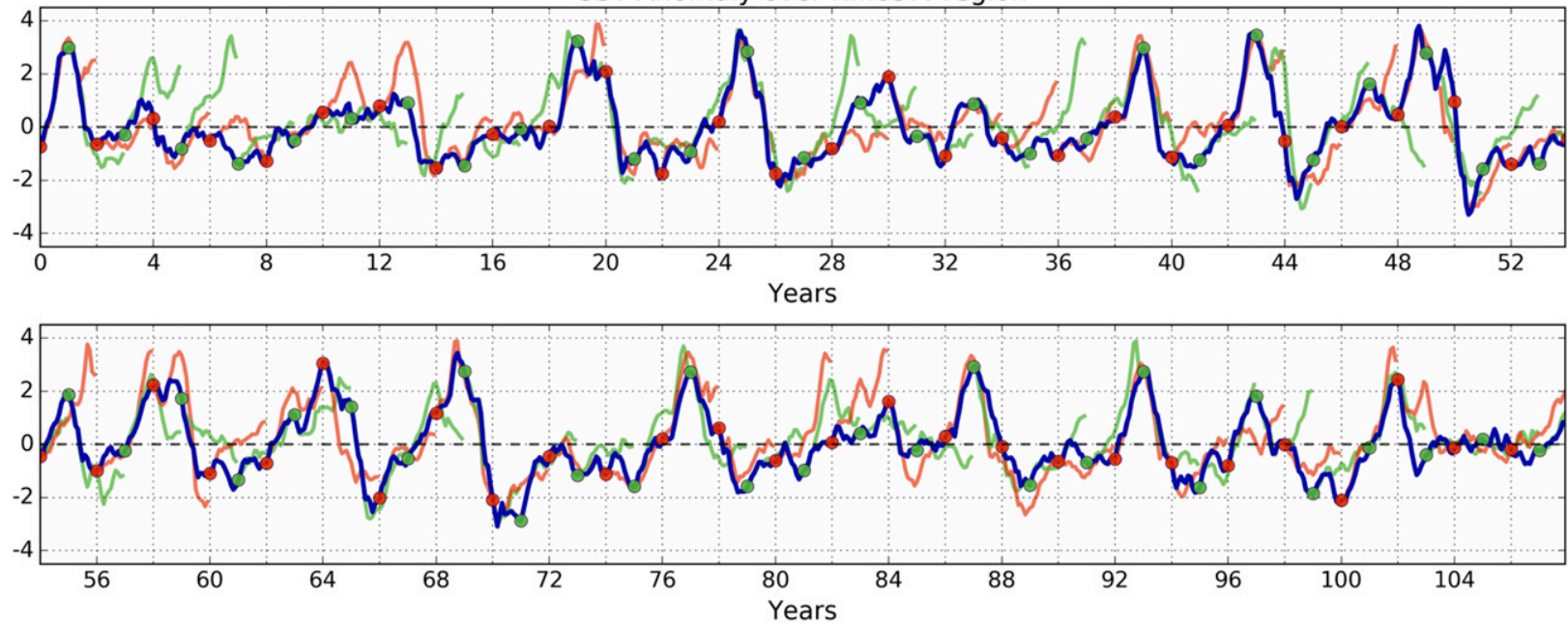

FIG. 1. Trajectories of Niño-3.4 SST anomalies for the 1850 S and 2000S runs. Trajectories are computed by averaging SST over the Niño-3.4 region and removing the annual cycle (calculated from 1850S). Blue curve is a 108-yr-long trajectory of a fully coupled control simulation (1850S). Red and green curves are 2-yr-long trajectories of fully coupled perturbed simulations (2000S) initialized every January (circles) from the control run. Red and green are used alternately to aid the visualization.

restricts adjustment to the upper ocean, and thus limits the influence of any deep oceanic transports in the climate model. In other words, it improves the signal (response)-to-noise (internal variability) ratio. Note that only the initial 2 years of the perturbed runs are shown in Fig. 1 and are primarily analyzed in this study. The subsequent 2 years are used to highlight the oscillatory nature of the tropical Pacific response.

Another pair of control and perturbed integrations were carried out using the slab-ocean model (SOM) in place of the full-ocean general circulation model (POP2), using a Q-flux calculated from 40 years of the $1850 \mathrm{~S}$ control run. These are respectively referred to as 1850S_som and 2000S_som. Use of SOM suppresses dynamical ocean feedbacks, and thus ENSO, from the coupled climate model and provides an opportunity to further explore sulfates and ENSO interaction. We refer to the two sets of experiments as fully and partially coupled experiments (Table 1). Due to the faster adjustment time scales of the partially coupled system, when compared to the fully coupled system, the perturbed integrations in this case were limited to 2 years. The absence of ENSO in the partially coupled system also allows us to reduce the ensemble size as aerosolinduced changes are easier to detect. To further differentiate between the slow ocean-mediated response and the fast atmosphere-only response, we also conducted a third set of control and 1-yr-long perturbed integrations with prescribed climatological SST from the fully coupled control simulation (1850S). These are referred to as 1850S_sst and 2000S_sst. We also generated another ensemble of 4-yr-long perturbed fully coupled integrations (2000S_2X) that were subjected to twice the amount of aerosol perturbation.

TABLE 1. Summary of model integrations. 1850 S refers to preindustrial sulfate aerosols. 2000 S refers to present-day sulfate aerosols.

\begin{tabular}{|c|c|c|c|c|}
\hline Model runs & Duration (yr) & Ensemble size & Spinup (yr) & Initial conditions \\
\hline \multicolumn{5}{|c|}{ Fully coupled (CAM5-POP) } \\
\hline $1850 \mathrm{~S}$ (control1) & 111 & 1 & 0 & Preindustrial spinup (from NCAR repository) \\
\hline $2000 \mathrm{~S}$ (transient) & 4 & 108 & 0 & Each January from control1 \\
\hline \multicolumn{5}{|c|}{ Partially coupled (CAM5-SOM) } \\
\hline 1850S_som (control2) & 80 & 1 & 20 & As in control1 \\
\hline 2000S_som (transient) & 2 & 50 & 0 & Each January from control2 \\
\hline \multicolumn{5}{|l|}{ Uncoupled } \\
\hline 1850S_sst (control3) & 30 & 1 & 0 & Preindustrial spinup (from NCAR repository) \\
\hline 2000S_sst (transient) & 1 & 29 & 0 & Each January from control3 \\
\hline \multicolumn{5}{|c|}{ Fully coupled (CAM5-POP) } \\
\hline 2000S_2X (transient) & 4 & 20 & 0 & Each January from control1 \\
\hline
\end{tabular}



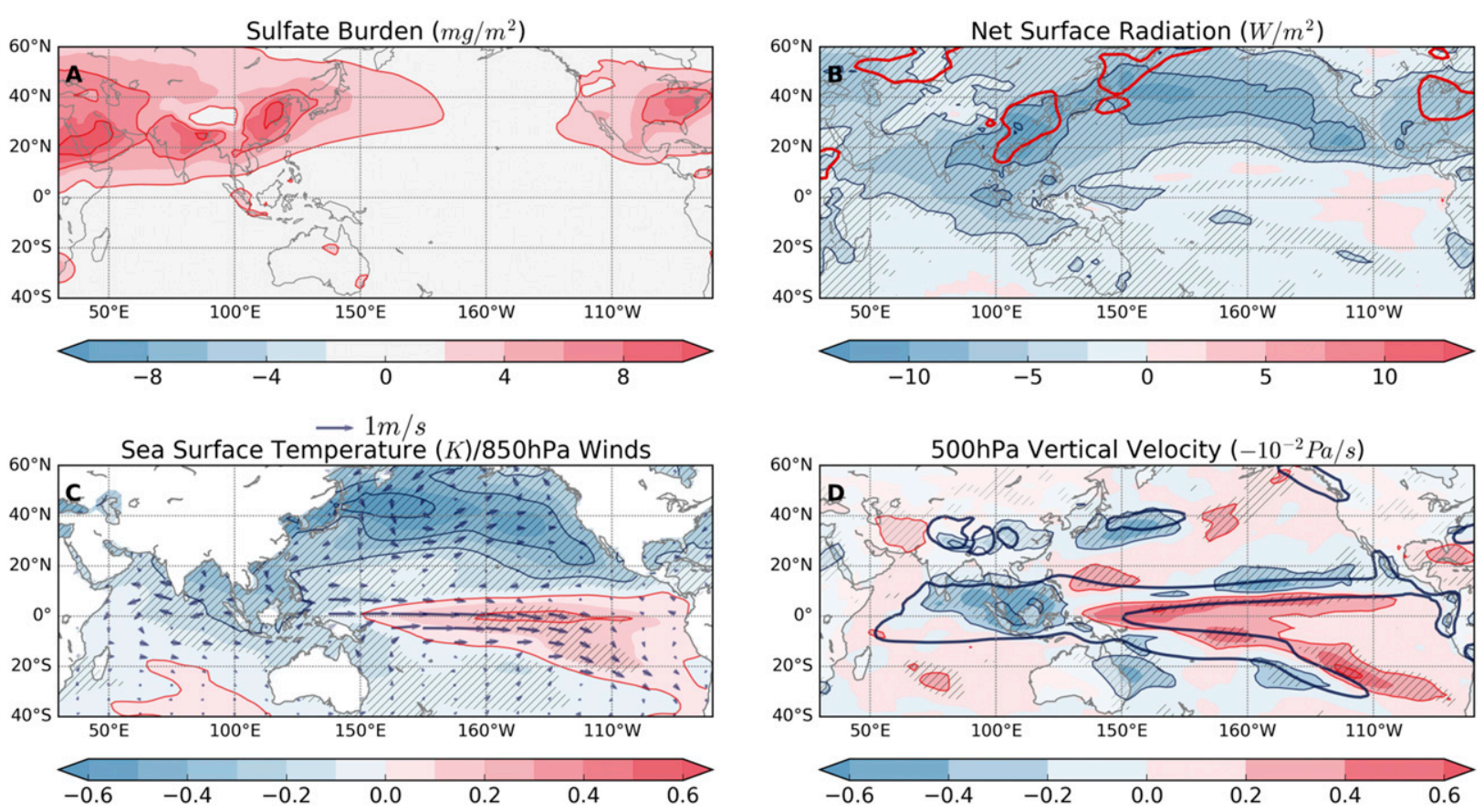

FIG. 2. Ensemble-mean first 2-yr mean differences between $2000 \mathrm{~S}$ and $1850 \mathrm{~S}$ runs. (a) Increase in column-integrated sulfate aerosol amount, (b) change in net surface radiation (positive into the surface; colors), (c) change in sea surface temperature (colors) and 850-hPa winds (vectors), and (d) change in 500-hPa vertical velocity (colors). Red contours $\left(-1.5 \mathrm{~W} \mathrm{~m}^{-2}\right)$ in (b) highlight regions with a maximum decrease in net surface radiation under clear-sky conditions. Blue contours $\left(0.02 \mathrm{~Pa} \mathrm{~s}^{-1}\right)$ in $(\mathrm{d})$ highlight regions with maximum 500 -hPa vertical velocity (tropical rainband) in 1850 S. Hatches indicate regions exceeding $90 \%$ statistical significance according to a standard $t$ test.

Specifically, we used CESM version 1.1 .2 (all components active) with $\sim 2^{\circ}$ finite-volume grid for the atmospheric component (CAM5) and a $\sim 1^{\circ}$ displacedpole grid for the oceanic component (POP2). These components had 30 and 60 levels in the vertical, respectively. Standard parameterizations for CAM5 include a moist turbulence scheme (Bretherton and Park 2009), deep convection (Neale et al. 2008), shallow convection (Park and Bretherton 2009), and a double-moment stratiform microphysics (Morrison and Gettelman 2008). (These choices correspond to the standard CESM configuration labels of B_1850_CAM5_CN and $1.9 \times 2.5$ _ gx1v6). CAM5 when compared to its predecessor shows improvements in modeling of aerosols (Liu et al. 2012), as well as their interaction with radiation and clouds (Ghan et al. 2012). The representation of ENSO in current-generation CESM has also been much improved with respect to its period, variability, asymmetry, and, to an extent, its spatial diversity (Capotondi et al. 2015a,b; Chen et al. 2017).

In next section, we will be isolating the transient response of the tropical Pacific to sulfate aerosol forcing. Most of the results presented are from the fully coupled experiment (2000S-1850S). The partially coupled experiment with SOM (2000S_som-1850S_som), and fixed-SST experiment (2000S_sst-1850S_sst) will be used to highlight the importance of dynamical oceanatmosphere coupling.

\section{Results}

\section{a. Mean response in fully, partially, and uncoupled experiments}

An increase in atmospheric aerosols reduces the amount of energy available to heat Earth's surface through scattering of solar radiation and modification of clouds. The initial 2-yr mean response to sulfate aerosols in the fully coupled experiment is shown in Fig. 2. The mean increase in the column-integrated sulfate aerosols during the first 2 years exhibits high concentrations in the vicinity of emission sources such as East and Southeast Asia (Fig. 2a). The notable increase in aerosols over the Northern Hemisphere is due to larger anthropogenic emissions in the Northern Hemisphere and atmospheric circulation that is primarily zonal on time scales relevant to the aerosol lifetimes. As a result, the corresponding net radiative imbalance at the surface (Fig. 2b) also exhibits hemispheric asymmetry. A greater reduction over the North Pacific Ocean, farther away from the aerosol maxima, is indicative of increase in cloud amount (in part from aerosol-cloud interaction). The direct effect, however, is largely confined 

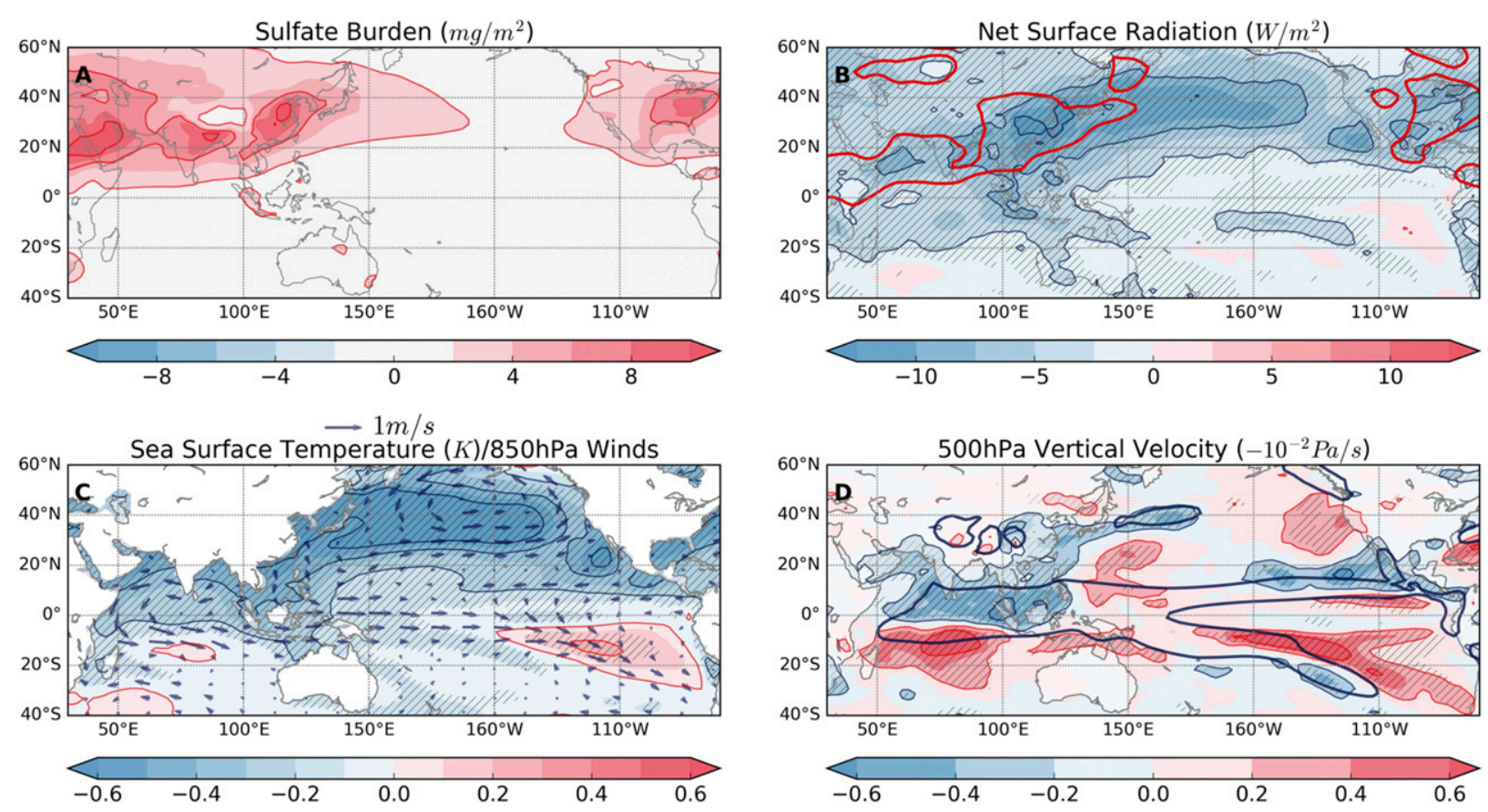

FIG. 3. Ensemble-mean 2-yr mean differences between the 2000S_som and 1850S_som runs. As in Fig. 2, but for the partially coupled experiment.

to regions closer to the emission sources with negative radiation anomalies under clear-sky conditions (red contours in Fig. 2b).

There is widespread cooling over the Northern Hemisphere oceans (Fig. 2c), similar to the pattern of reduced radiation (Fig. 2b). Over the northern Pacific, the decrease in SST is accompanied with cyclonic lower-level wind response (vectors in Fig. 2c), suggesting weakening of the subtropical high and/or strengthening of the Aleutian low. Surprisingly, the tropical eastern Pacific Ocean exhibits warming along the equatorial region, which then extends southeast to $20^{\circ} \mathrm{S}$. This warming is accompanied by a westerly (or northwesterly) wind response over the tropics and could be related to changes either in equatorial ocean dynamics or in turbulent heat fluxes, sometimes referred to as dynamic versus thermodynamic coupled response. In this study, we primarily focus on the role of equatorial ocean dynamics in the aforementioned warming, and its impacts on the tropical atmospheric circulation.

The response of the midtropospheric vertical velocity, which is closely related to the precipitation (Fig. 2d), shows a significant decrease over the Maritime Continent and increase just north of the eastern Pacific cold tongue. This zonally asymmetric response over the tropical Pacific is consistent with the underlying zonal asymmetry in the SST response (Fig. 2c). Superimposed on this zonally asymmetric atmospheric response is a band of negative (along $10^{\circ} \mathrm{N}$ ) and positive (along the equator) anomalies especially over the eastern tropical Pacific, which could be interpreted as a regional outcome of a southward shift of the zonal mean ITCZ (Fig. 2d). We find that on interannual time scales, the anthropogenic sulfate aerosols can have significant impacts on the Walker cell in addition to the well-studied southward shift of the ITCZ.

Next the partially coupled response where the ocean is treated as a slab is compared to the fully coupled response (Fig. 3). Despite similarities in the large-scale response simulated in the partially and the fully coupled cases, there are significant regional differences. The most notable are changes in tropical vertical motion and warming of the eastern tropical Pacific. There is a stronger southward shift of the ITCZ, but a weaker Walker cell response in the partially coupled experiment where ocean dynamics and associated feedbacks are omitted. Their inclusion in the fully coupled experiment, however, allows warming of the equatorial region as compared to exclusively off-equatorial warming in the partially coupled case. Henceforth, we study this equatorial response to sulfate aerosol forcing and defer the origin of the thermodynamic off-equatorial response to a future study.

The fixed SST can be used to separate out the fast, atmospheric adjustment in response to increased aerosols (Fig. 4). The reduction in net surface radiation 

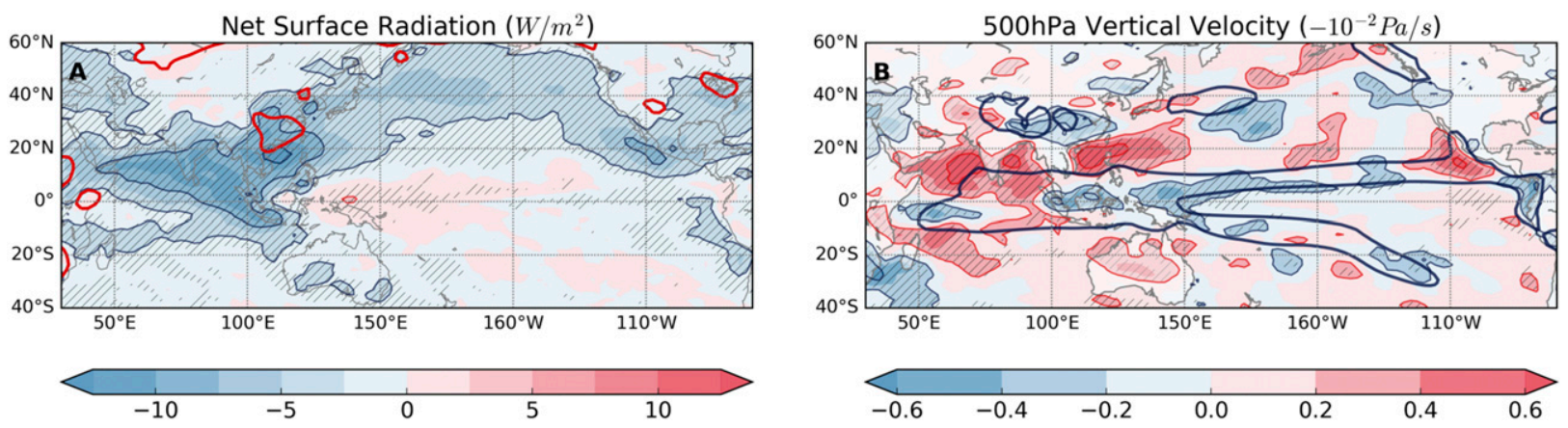

FIG. 4. Ensemble-mean 1-yr mean differences between the 2000S_sst and 1850S_sst runs. As in Figs. 2b and 2d, but for the uncoupled experiment.

(Fig. 4a) has an imprint of the sulfate aerosols burden in the atmospheric column. As opposed to the fully and partially coupled cases, the largest reduction in surface radiation is seen over the East and Southeast Asian region instead of over the North Pacific. This points to cloud-SST feedback playing an active role over the extratropical oceans when SST is allowed to evolve. The response in midtropospheric vertical velocity, and hence precipitation, is noisier (Fig. 4b). The Walker cell undergoes opposite changes with substantial ascent over the tropical Indian Ocean (perhaps due to a change in land-sea thermal contrast) and descent over the equatorial Pacific when compared to essentially the opposite with prognostic SST. This indicates that the Walker cell response in fully and partially coupled integrations is primarily controlled by aerosol-induced sea surface cooling.

\section{b. Time evolution of fully and partially coupled response}

To understand the dynamical origins of equatorial warming, we compare spatiotemporal evolution (averaged between $5^{\circ} \mathrm{S}$ and $5^{\circ} \mathrm{N}$ ) of zonal wind stress, SST, and upper-ocean heat content responses between fully and partially coupled experiments (Fig. 5). In the fully coupled case, the eastern Pacific warming undergoes seasonal modulation with maximum warming during the winter months (Fig. 5c). The warming is not limited to the sea surface alone but extends to the subsurface, resulting in a similar evolution of upper-ocean heat content response (Fig. 5e). Note that the equatorial warming is absent in the partially coupled case (Figs. 5d,f).

The warm anomalies over the equator are preceded by a westerly wind stress response (Fig. 5a). There are collocated wind stress and SST maxima during winter months in the central Pacific. Another maximum in westerly wind stress is seen over the west Pacific during early summer months, prior to the warming. These wind stress maxima are also observed in the partially coupled response (Figs. 5a,b). However, the amplitude only grows from the first year to the second year in the fully coupled case, which suggests the presence of a positive ocean-atmosphere feedback. This points to the importance of upper equatorial ocean dynamics in the climate system response to sulfate aerosol forcing.

\section{c. Tropical Pacific atmospheric and oceanic circulation response}

A cross section of temperature response across the Pacific Ocean (averaged between $5^{\circ} \mathrm{S}$ and $5^{\circ} \mathrm{N}$ ) during October-December of the second year is shown in Fig. 6a. This period corresponds to the maximum warming along the equatorial region. A dipolar pattern with warm anomalies on the eastern side and cold anomalies on the western side of the basin is present with local maxima located around $100 \mathrm{~m}$ below the ocean surface. The pattern is characteristic of an El Niño event where a "seesaw-like" displacement of the equatorial thermocline results in opposite anomalies on either side of the basin. Deepening of the thermocline in the east weakens cooling by equatorial upwelling, while its shoaling in the west could strengthen it (Neelin 2010). The spatial subsurface temperature $(105 \mathrm{~m})$ response exhibits off-equatorial cold anomalies to the north and the south of the equator, which represent thermocline shoaling, indicative of an off-equatorial ocean response to cyclonic wind stress curl anomalies (Fig. 6b).

The tropical Pacific mean ocean temperature is zonally asymmetric (warm pool and cold tongue) and is maintained by a complex upper-ocean circulation system (vectors in Fig. 6c) that includes the South Equatorial Current (SEC), a westward-flowing surface current, and the Equatorial Undercurrent (EUC), a narrow eastward-flowing subsurface current. The response in this equatorial circulation system to sulfate aerosols (shading in Fig. 6c) has an eastward anomaly in the surface ocean and a westward anomaly in the 
Zonal Wind Stress
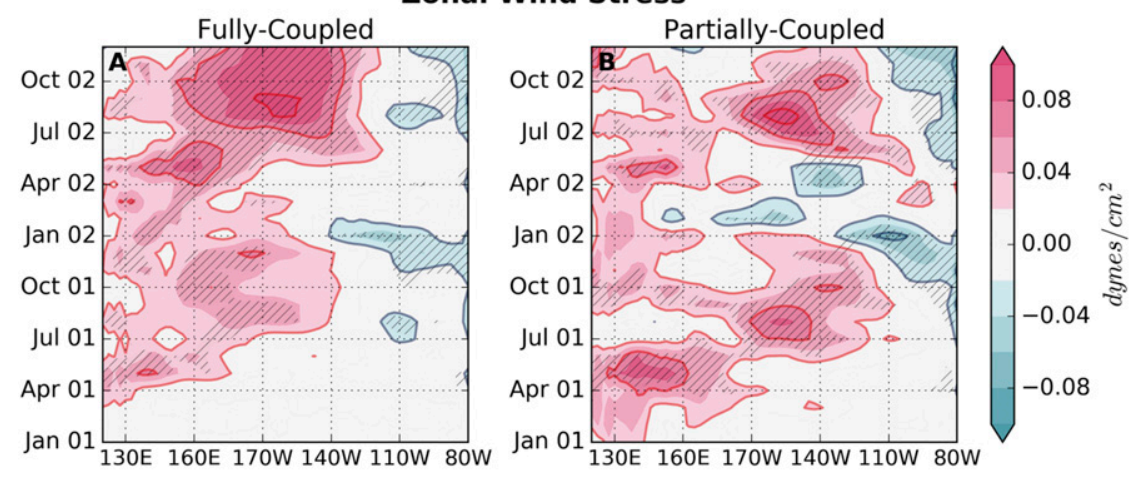

\section{SST}
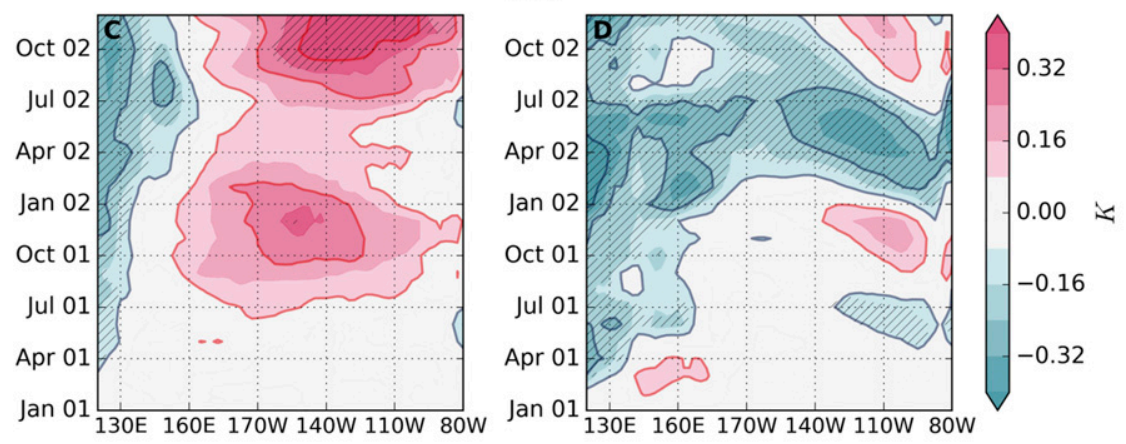

Heat Content
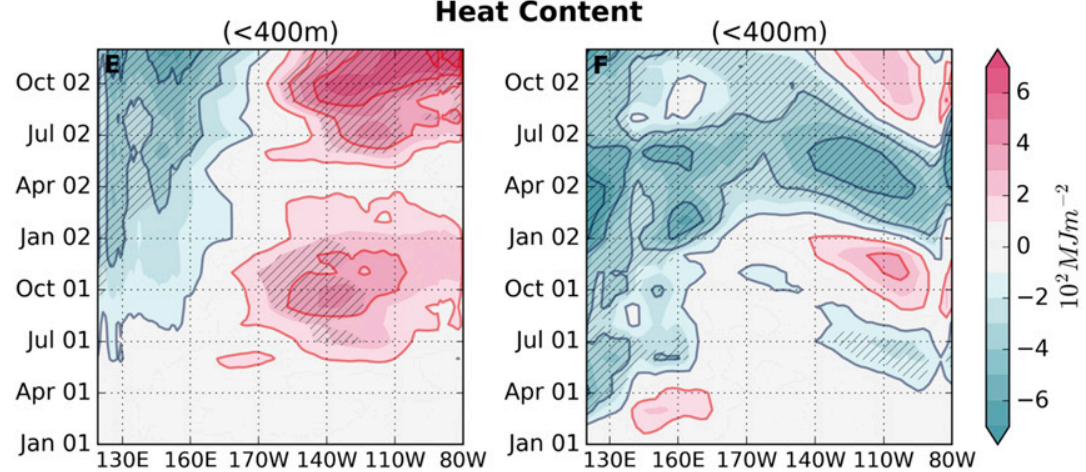

FIG. 5. Ensemble-mean monthly mean differences (a),(c),(e) between the $2000 \mathrm{~S}$ and $1850 \mathrm{~S}$ runs and (b),(d),(f) between the 2000S_som and 1850S_som runs over the equatorial Pacific $\left(5^{\circ} \mathrm{S}-5^{\circ} \mathrm{N}\right)$. Initial 2-yr evolution of (a) zonal wind stress, (c) sea surface temperature, and (e) upper-ocean heat content (up to 400-m depth) responses in the fully coupled experiment and 2-yr evolution of (b) zonal wind stress, (d) sea surface temperature, and (f) upper-ocean heat content responses in the partially coupled experiment. Hatches indicate regions exceeding $90 \%$ statistical significance according to a standard $t$ test.

subsurface ocean, which amounts to a slowdown of the SEC-EUC system, thereby causing an accumulation of heat on the eastern side of the basin. From an oceanic perspective, the equatorial westerly wind stress response to aerosols is responsible for the warming in the eastern equatorial Pacific and the associated circulation changes (Fig. 6d).

From an atmospheric perspective, the westerly wind stress response over the western Pacific is part of changes to the large-scale Walker circulation. The ascending branch of this zonal atmospheric cell, which is typically located around the Maritime Continent and western Pacific, is perturbed in response to increased sulfate aerosols. The atmospheric response to increased sulfate aerosols averaged over April-June of the second year is shown in Fig. 7. This period corresponds to the wind stress maxima over the western Pacific prior to the peak warming. Following Schwendike et al. (2014), the change in strength of the local Walker cell can be diagnosed using a vertical cross section of change in 

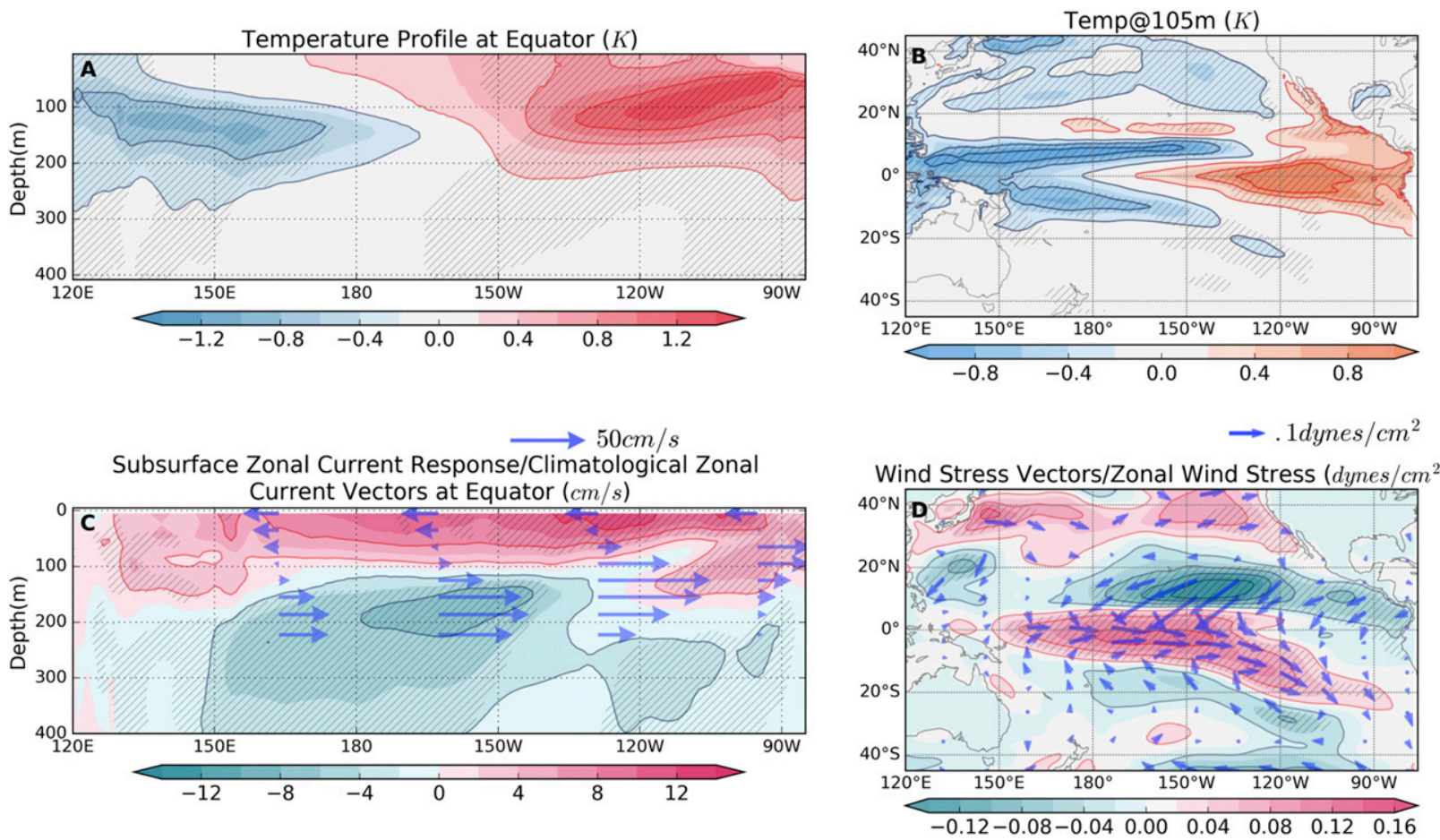

FIG. 6. Ensemble-mean second-year October-December mean differences between the 2000S and 1850S runs. (a) Equatorial cross section $\left(5^{\circ} \mathrm{S}-5^{\circ} \mathrm{N}\right)$ of temperature response. (b) Temperature response at $105-\mathrm{m}$ depth below the surface. (c) Equatorial cross section $\left(5^{\circ} \mathrm{S}-5^{\circ} \mathrm{N}\right)$ of zonal current response (colors) and vectors of climatological zonal currents based on the 1850S run. (d) Zonal wind stress (colors) and wind stress vector responses. Hatches indicate regions exceeding $90 \%$ statistical significance according to a standard $t$ test.

zonal vertical mass flux averaged meridionally over $10^{\circ} \mathrm{S}-$ $10^{\circ} \mathrm{N}$ (Fig. 7a). The anomalous circulation response shows descent over the Indian Ocean and ascent over the western Pacific centered on the date line. The low-level westerlies over the equatorial western Pacific, which impart westerly momentum to the underlying ocean, form the lower limb of this anomalous circulation.

Figures $7 \mathrm{~b}-\mathrm{d}$ display the corresponding responses in precipitation, low-level $(850 \mathrm{hPa})$ winds, and upperlevel $(\sim 300 \mathrm{hPa})$ divergence. As expected, all of them indicate the presence of large-scale subsidence over East Asia as was seen in Fig. 7a. The significant reduction in precipitation (Fig. 7b) over East Asia is related to anomalous downward motion that diverges in lower levels with westerlies to the west and easterlies to the east of the Maritime Continent (Fig. 7c). The nonzero convergence (Fig. 7d) in the upper levels close to the equator also confirms the perturbed Walker cell in response to aerosol forcing.

The Walker circulation response when the warming is greatest (i.e., October-December of the second year) is weaker and shifted eastward relative to the April-June response (cf. Figs. 7a and 8a), which gives rise to westerly wind anomalies over the central/eastern Pacific instead of the western Pacific (cf. Figs. 7c and 8c). The zonal asymmetry in precipitation is also reduced during the winter months (Fig. 8b) and no significant upperlevel equatorial convergence over the Maritime Continent is observed (Fig. 8d).

\section{d. Equatorial ocean wave adjustment}

Spatial maps showing the vertically integrated ocean temperature response (down to 400-m depth) illustrate the growth of the equatorial warming during the first year (Figs. 9a-d). The warm (positive) anomaly in vertically integrated temperature implies deepening of the thermocline. The anomaly first appears during May when westerly wind stress response is confined to the west, closer to the Asian continental emissions. Later, the anomaly grows and moves eastward and peaks during October. The eastward propagation of the warm anomaly and its spread along the coast is suggestive of downwelling equatorial and coastal Kelvin waves. The reflection of the equatorial Kelvin wave from the eastern boundary into the downwelling off-equatorial Rossby wave can also be seen in the westwardpropagating warm anomaly over the northern tropics (near the Central American coast) (Figs. 9c,d). The equatorial warming can therefore be understood in terms of the aforementioned equatorial wave dynamics. 

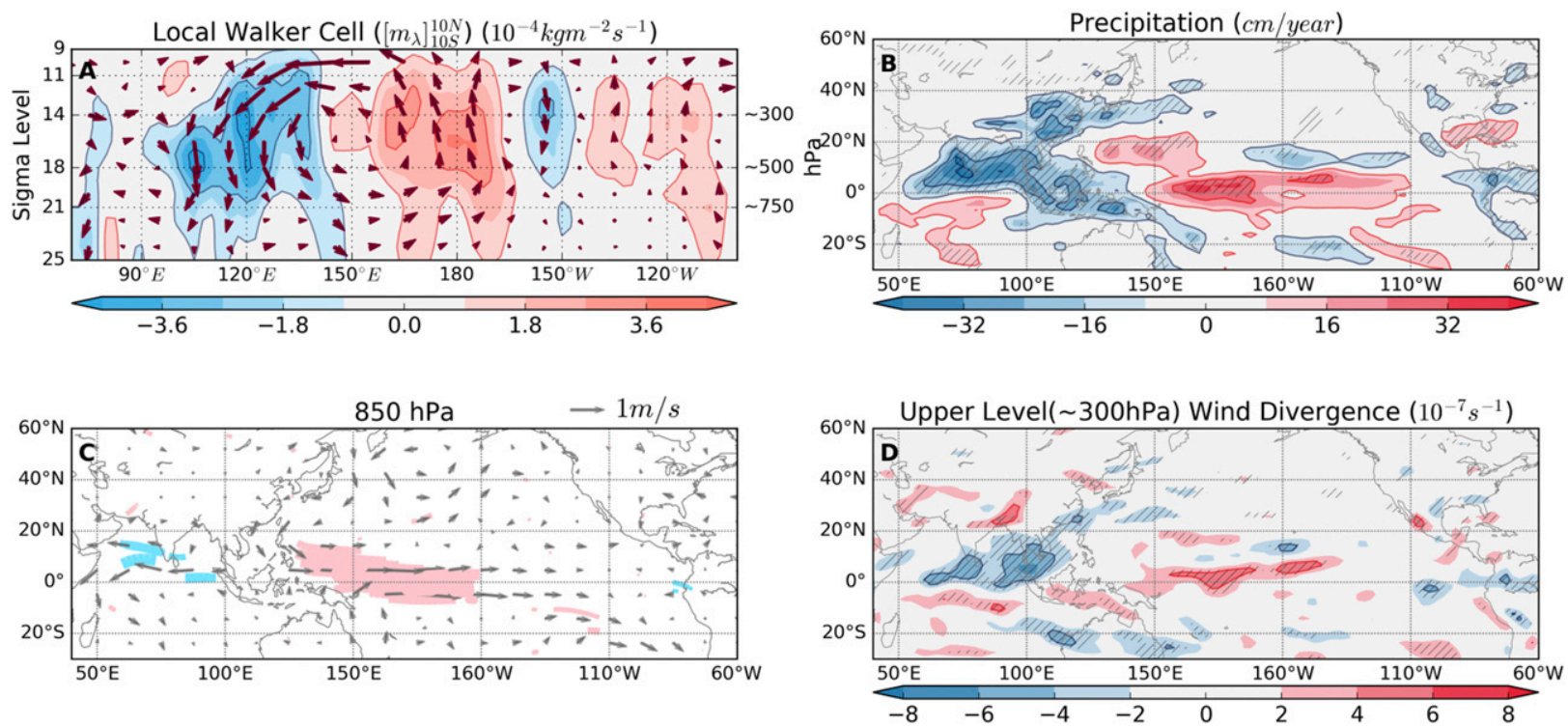

FIG. 7. Ensemble-mean second-year April-June mean differences between the 2000S and 1850S runs. (a) Local Walker cell response (vertical mass flux partitioned into zonal direction) averaged over $10^{\circ} \mathrm{S}-10^{\circ} \mathrm{N}$ (colors) along with the corresponding winds response (vectors). (b) Precipitation response. (c) $850-\mathrm{hPa}$ wind response (vectors), with colors indicating regions of statistically significant zonal wind response (blue for easterly; red for westerly). (d) Changes in divergence at model level $=14(\sim 300 \mathrm{hPa})$ between $2000 \mathrm{~S}$ and $1850 \mathrm{~S}$. Hatches indicate regions exceeding $90 \%$ statistical significance according to a standard $t$ test.

The off-equatorial thermocline response of negative vertically integrated temperature can be largely explained through changes in the wind-driven Ekman pumping/suction, driven by the anomalous curl of wind stress (Figs. 9e-h). Negative off-equatorial anomalies (black boxes in Fig. 9c) on either side of the equator are associated with shoaling of the thermocline driven by cyclonic wind stress curl anomalies that are positive (negative) in the northern (southern) tropics. During December of the first year (Fig. 9h), a band of positive wind stress curl, which stretches across the northern basin, brings colder water upward. This wintertime increase in wind stress curl is observed during all four years (not shown) of the simulation and could be
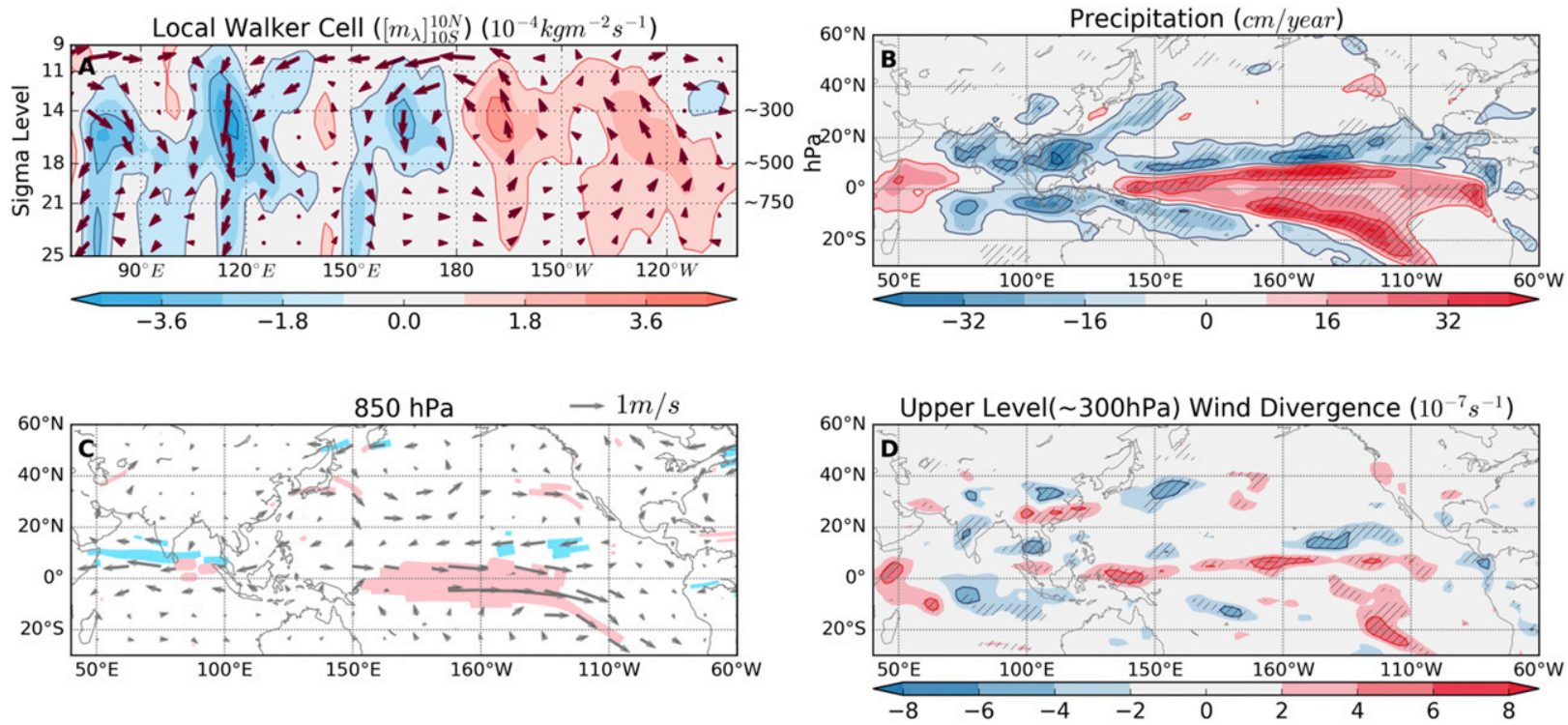

FIG. 8. Ensemble-mean second-year October-December mean differences between the 2000S and 1850S runs. As in Fig. 7, but for the following winter season. 
Integrated Ocean Temperature $(0-400 m ; m K)$
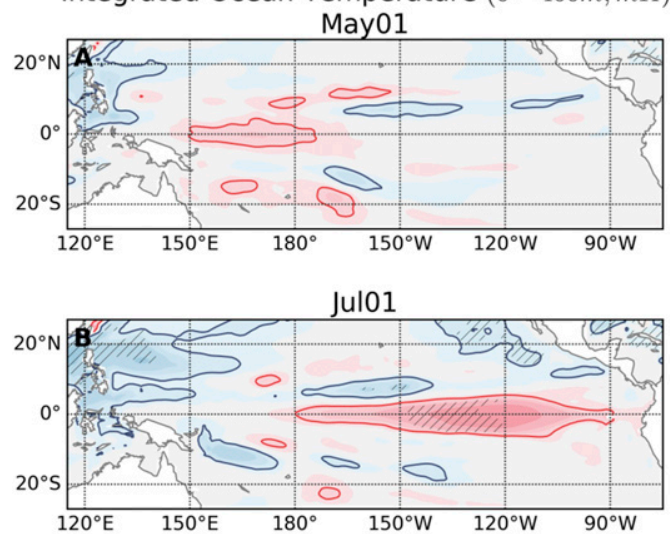

Oct01
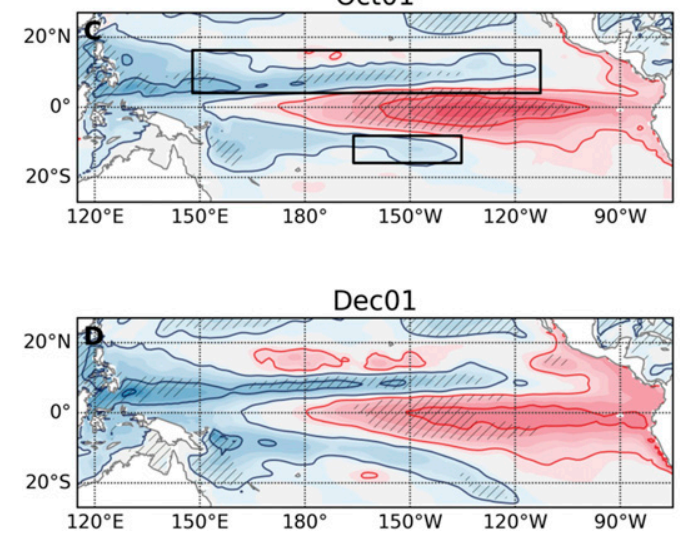
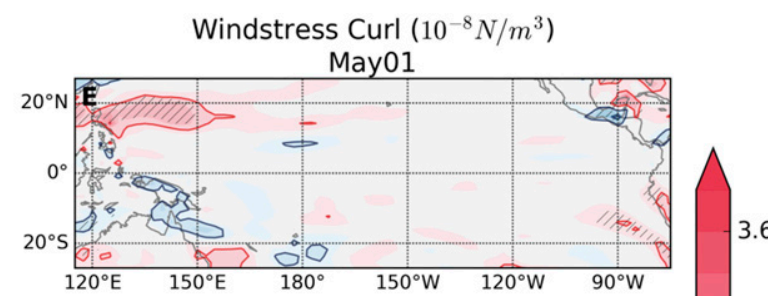

$-80$

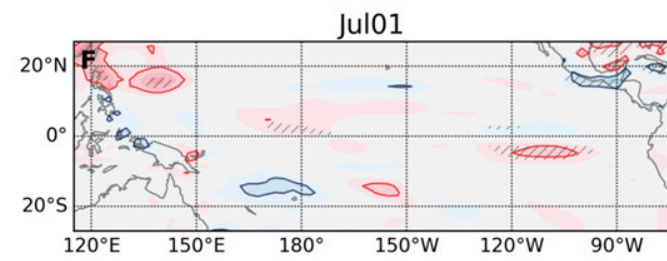

$-2.4$

$-30$

0

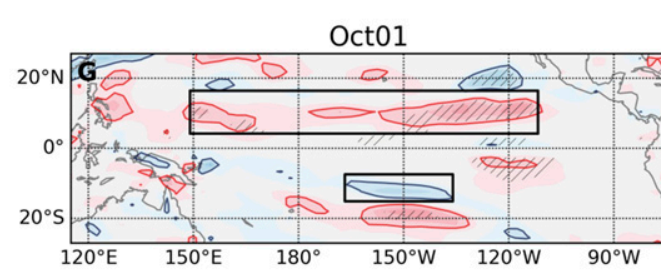

$-0.0$

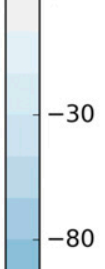

$-140$

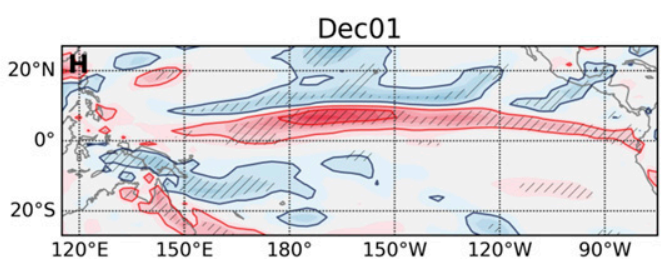

3.6

1.2

$-3.6$

FIG. 9. Ensemble-mean monthly mean differences between the $2000 \mathrm{~S}$ and $1850 \mathrm{~S}$ runs. (a)-(d) Vertically integrated temperature (down to 400-m depth) response for May, July, October, and December, respectively, of the first year, and (e)-(h) corresponding vertical component of the curl of wind stress response. Hatches indicate regions exceeding $90 \%$ statistical significance according to a standard $t$ test.

contributing to the seasonal decay of the warm anomaly.

\section{e. Relationship between surface wind stress and SST anomalies}

Cross-correlation between the Niño-3.4 SST response and zonal wind stress response for different lags and leads can establish the role of westerly wind stress response in setting up of equatorial warming (Fig. 10). The highest positive correlations (up to 0.75) are found over the equatorial regions, confirming the direct dependence of the equatorial warming on the westerly wind stress response. The significant positive correlation first appears over the western Pacific about 8 months prior to the peak warming. Subsequently, the correlation grows and moves eastward along the equatorial region. It peaks over the central Pacific at zero lag and then starts to decay with increasing lead times, indicative of the Bjerknes feedback. Of the two maxima in wind stress response shown earlier in Fig. 5a, the one over the western Pacific leads and the one over the central Pacific is in phase with the warming. We further examine the relationship by cross correlating the area averaged time series of 1) the Niño-3.4 SST response with that of local wind stress response and 2) the Niño-3.4 SST response with that of remote west Pacific wind stress response (Fig. 11a). The asymmetry around zero lag in the latter case reiterates that warming is remotely forced (at least partially) by the western Pacific westerly wind stress response. On the other hand, the symmetric curve in the former case implies local coupling between wind stress and SST responses, which might enhance the coupled response. Therefore, equatorial Pacific warming is remotely initiated by the springtime westerly wind stress response over the far west through changes in the equatorial thermocline and subsequently intensified by a positive feedback between the anomalous winds and SST — an important element of the Bjerknes feedback. 
Lag 8

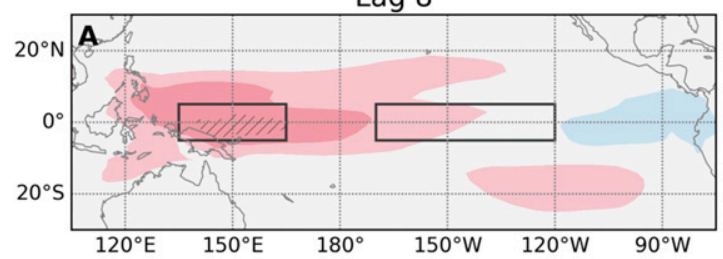

Lag 5

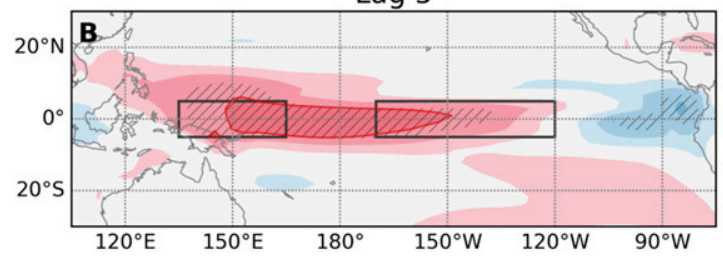

$\operatorname{Lag} 2$

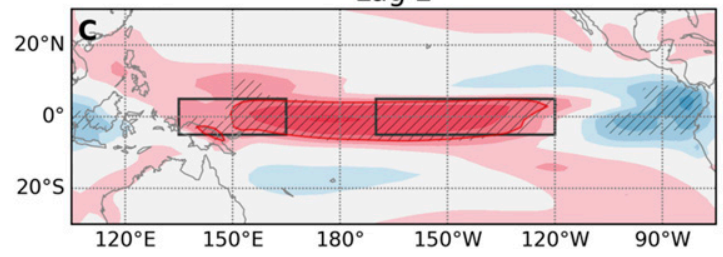

Lag 0

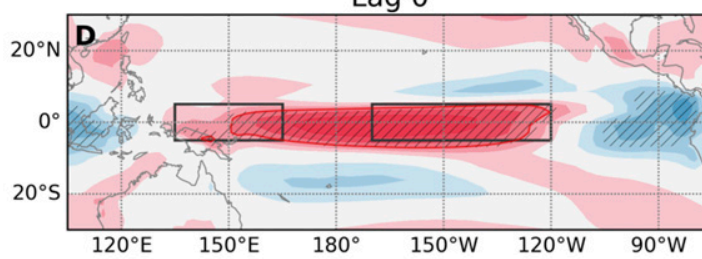

Lead 2

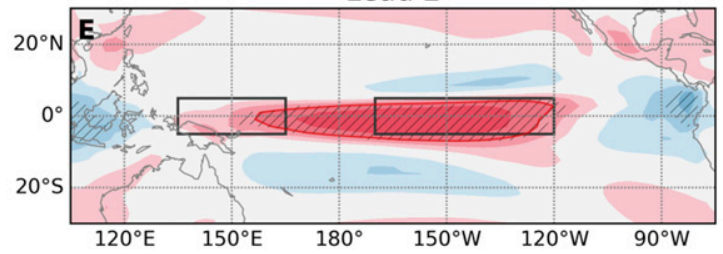

Lead 5

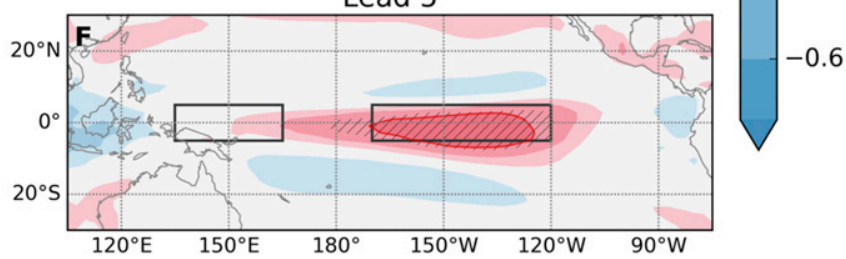

FIG. 10. Ensemble-average lead-lag cross correlation between Niño-3.4 SST response (2000S-1850S) and zonal wind stress response (2000S-1850S) in a fully coupled experiment. Change in zonal wind stress between 2000S and 1850S at each grid point is correlated to the corresponding Niño-3.4 $\left(5^{\circ} \mathrm{S}-5^{\circ} \mathrm{N}, 170^{\circ}-120^{\circ} \mathrm{W}\right.$; shown as a box over the central Pacific) SST change for SST lagging wind stress by (a) 8 , (b) 5, (c) 2, and (d) 0 months and SST leading wind stress by (e) 2 and (f) 5 months. Hatches indicate regions exceeding $90 \%$ statistical significance based on a standard test using $t$ statistics. The box outlined over the tropical west Pacific is used in Fig. 11.

\section{f. Subsequent cooling and nonlinear dependence on background Niño state}

We extended analysis of the evolution of the equatorial response in the fully coupled case to another 2 years. The overall time series of 4-yr evolution along with the 12-month running mean over the Niño-3.4 region is shown by the blue curve in Fig. 11c. The corresponding spatial evolution shows that the warming is observed for another year and then replaced by
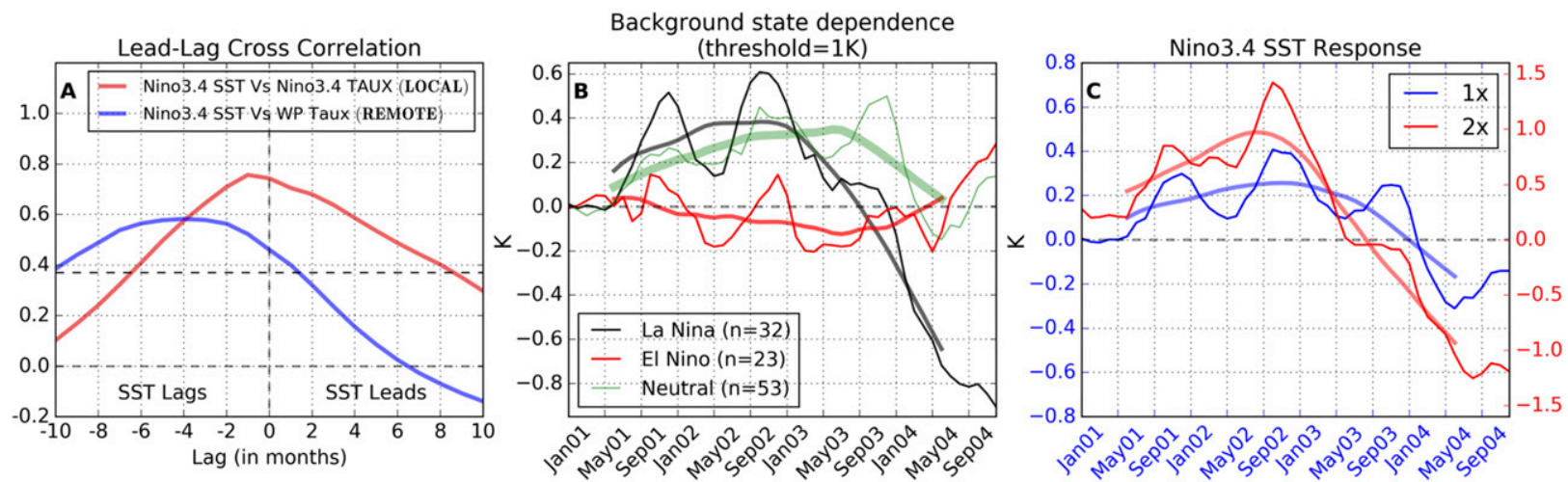

FIG. 11. (a) Ensemble-average lead-lag cross-correlation between area-averaged time series of SST and zonal wind stress responses (2000S-1850S). Red curve shows cross-correlation function between Niño-3.4 SST response and Niño-3.4 zonal wind stress response (local interaction). Blue curve shows the cross-correlation function between Niño-3.4 SST response and tropical west Pacific zonal wind stress response (remote forcing). These regions are outlined in Fig. 10. (b) Composites of ensemble-mean Niño-3.4 SST changes between 2000S and $1850 \mathrm{~S}$. These composites were created by comparing the Niño-3.4 index at the start of the run against a 1-K threshold. (c) Areaaveraged (over Niño-3.4 region) ensemble-mean monthly mean SST changes between $2000 \mathrm{~S}$ and $1850 \mathrm{~S}$ ( $1 \times$; blue; left axis) and between 2000S_2x and 1850S (2×; red; right axis) for fully coupled experiments. 

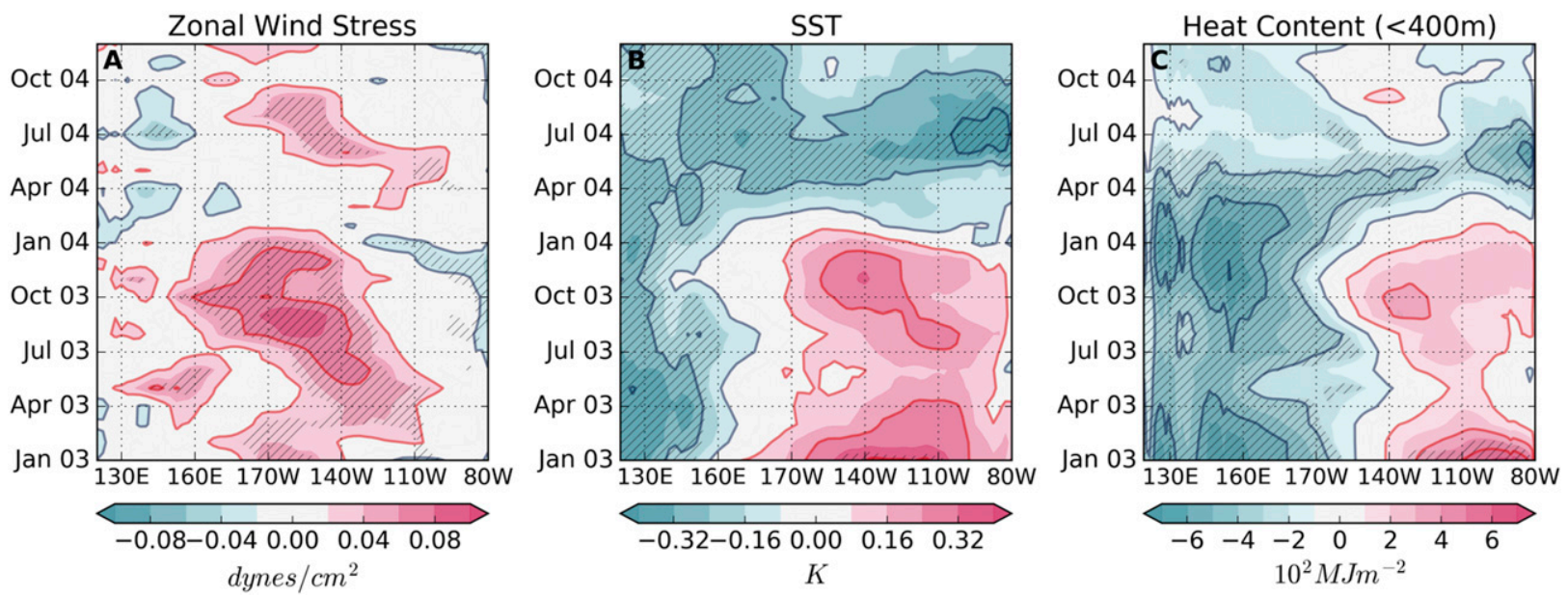

FIG. 12. Ensemble-mean monthly mean differences between the $2000 \mathrm{~S}$ and $1850 \mathrm{~S}$ runs over the equatorial Pacific $\left(5^{\circ} \mathrm{S}-5^{\circ} \mathrm{N}\right)$. Last-2-yr evolution of (a) zonal wind stress, (b) sea surface temperature, and (c) upper-ocean heat content (up to 400-m depths) responses in the fully coupled experiment. Hatches indicate regions exceeding $90 \%$ statistical significance according to a standard $t$ test.

basinwide cooling in the fourth year (Fig. 12b). The associated westerly wind stress response reduces and shrinks in its extent during an anomalously cold equatorial Pacific in the fourth year (Fig. 12a). The phase reversal during the fourth year implies the transient nature of the observed warming response. Preliminary analysis reveals (not shown) that subsequent wave adjustments akin to those during El Niño-to-La Niña transitions could be responsible for this reversal. At this point, the role of the surface cooling that propagates from the North Pacific (not shown) is not clear but it could conceptually be responsible for the phase reversal through thermodynamic air-sea interactions akin to those implicated in the formation of central Pacific El Niño (Yu et al. 2010). The mechanism of this phase reversal along with its time scale $(\sim 3 \mathrm{yr})$ will be explored in another follow-up study. The Niño-3.4 SST response to doubled aerosol perturbation exhibits similar time evolution except for the magnitude (Fig. 11c). Since the time scale of the response is independent of the amount of aerosols, it must therefore depend solely on internal climate dynamics. The threefold increase in warming (to doubled aerosol perturbation), on the other hand, highlights inherent nonlinearity.

Similar to ENSO nonlinearity, the tropical Pacific response also shows nonlinear dependence on the background ENSO state. Figure 11b highlights this asymmetry by compositing the Niño-3.4 response based on the phase of the initial condition. The growth of seasonal warming for the initial 3 years followed by the phase reversal in the fourth is a characteristic response when runs were initialized in a La Niña or neutral state. On the contrary, when initialized during an El Niño phase, it shows moderate cooling with superimposed seasonal variations.

\section{g. Role of aerosol forcing}

We have demonstrated the dynamical forcing of the ocean by the atmosphere circulation response, but how do sulfate aerosols first affect the tropical zonal atmospheric circulation? The SST and gradients of SST play important roles in driving tropical circulation (Gill 1980; Lindzen and Nigam 1987; Sobel 2007). We suggest that the local cooling induced by increased sulfate aerosols over East Asia (specifically western Pacific SST), in conjunction with moist convection, gives rise to the local circulation response. Since the cooling is restricted to the western tropical Pacific (Fig. 5b), there is a largescale zonal asymmetry in the SST and circulation response. The absence of a comparable tropical atmospheric circulation response in the fixed-SST experiment confirms this hypothesis that aerosol-induced surface cooling results in Walker cell changes, and subsequent equatorial dynamical ocean adjustment.

\section{Conclusions}

This study addresses the transient response of the equatorial Pacific Ocean to an abrupt increase in tropospheric sulfate aerosols using a series of climate model experiments with different degrees of oceanatmosphere coupling. This model hierarchy highlights the role of ocean dynamics in modulating the equatorial Pacific response on seasonal to interannual climate time scales. We identify the mechanisms by which aerosols can modify the tropical atmospheric circulation, thus 
affecting ocean dynamics, and trigger a coupled oceanatmosphere response.

In addition to the southward shift of the ITCZ in response to anthropogenic sulfate forcing, the tropical circulation exhibits significant weakening of the Walker cell. The weakening is caused by aerosol-induced cooling of the tropical Indian and western Pacific Oceans that results in reduced precipitation over the Maritime Continent and increased precipitation over the Pacific to the east. The resulting anomalous surface westerlies, through thermocline dynamics, warm the upper eastern equatorial Pacific Ocean similar to the initiation and growth of El Niño (Neelin 2010). This equatorial warming in response to westerly wind stress is not simulated by the slab-ocean model confirming the ocean dynamical origins of the warming. Besides the dissimilar ocean response, the thermodynamic coupling (with a slab ocean) causes a stronger southward shift of the tropical rain belt and weaker eastward shift (or the weakening) of the Walker cell. The results are consistent with the recent study by Green and Marshall (2017), which links reduced extent of the ITCZ shift to increased degree of ocean-atmosphere coupling. The present study highlights the need to represent dynamical ocean-atmosphere feedbacks (Xie 1998; Chang 1996) to accurately simulate the tropical Pacific response to changes in aerosol concentration.

Both atmospheric and oceanic responses exhibit strong seasonality. The westerly wind stress response has two maxima, one over the western Pacific during May and another over the central Pacific during October. These are related to the changes in the Walker circulation. There is a stronger atmospheric overturning response over the Maritime Continent during May that weakens and shifts eastward in October. The wind stress maxima are simulated irrespective of the choice of the ocean model and play an integral part in the warming of the underlying ocean in the fully coupled case. The earlier event initiates the thermocline adjustment and warming of the upper ocean, whereas the later event enhances the warming due to local ocean-atmosphere coupling. The warming first appears in the west during early summer, grows, and propagates eastward and peaks along with the wind stress maxima over the central Pacific. This constitutes the initiation and the growth phase of the seasonal warming. It is followed by the decay partially caused by off-equatorial Ekman suction and poleward meridional advection along the eastern boundary. Earlier studies show that the seasonal cycle over the tropical Pacific plays an important role in setting up ENSO's interannual variability (Xie 1995; Chang et al. 1995). Whether seasonality of the response to aerosols is controlled by emissions or by mechanisms internal to the tropical Pacific climate system is an important problem, and needs further investigation.

This seasonal equatorial warming response is observed for the initial 3 years followed by the phase reversal (cooling) in the fourth year. The phase reversal is brought about by eastward-propagating upwelling Kelvin waves along the equator resulting from the upwelling Rossby waves (not shown), in accordance with the delayed oscillator paradigm for ENSO (Neelin 2010; Wang and Picaut 2004). The timing of the phase reversal stays almost fixed even when the aerosol perturbation is doubled. This demonstrates that barring seasonal modulation, initial growth of the warm anomaly followed by the phase reversal is driven by the Bjerknes feedback and upper-ocean equatorial wave dynamics. In summary, the abrupt increase in anthropogenic sulfate aerosols gives rise to a seasonally modulated damped oscillation of the equatorial Pacific through Bjerknes feedback and wave adjustments in the upper equatorial ocean.

Aerosols, natural or anthropogenic, are an integral part of the climate system. Long-term changes in aerosols have caused large-scale shifts in past climates, whereas on the shorter time scales the regional climate is significantly affected. In particular, increasing aerosols (or even varying aerosols) over East and Southeast Asia can potentially affect the tropical Pacific climate on seasonal to interannual time scales, provided the perturbation is large enough. For example, the twofold increase in aerosol perturbation gives rise to around a threefold increase in the tropical Pacific warming. Unlike the previous case, the warming here reaches up to $1.5^{\circ}$ at the end of second year and rivals the background Niño state. These results are consistent with those presented by Ohba et al. (2013) and Stevenson et al. (2016) for the response to volcanic eruptions. They showed that rapid land cooling around the Maritime Continent, weakening of zonal SST gradients, and associated change in Walker circulation result in an El Niño a year after a tropical volcanic eruption. Changes in tropospheric aerosol emissions could conceivably play an important role in modulating tropical climate.

\section{REFERENCES}

Allen, R. J., A. T. Evan, and B. B. B. Booth, 2015: Interhemispheric aerosol radiative forcing and tropical precipitation shifts during the late twentieth century. J. Climate, 28, 8219-8246, https://doi.org/10.1175/JCLI-D-15-0148.1.

Ammann, C. M., W. M. Washington, G. A. Meehl, L. Buja, and H. Teng, 2010: Climate engineering through artificial enhancement of natural forcings: Magnitudes and implied consequences. J. Geophys. Res., 115, D22109, https://doi.org/10.1029/ 2009JD012878. 
Biasutti, M., and A. Giannini, 2006: Robust Sahel drying in response to late 20th century forcings. Geophys. Res. Lett., 33, L11706, https://doi.org/10.1029/2006GL026067.

Bollasina, M. A., Y. Ming, and V. Ramaswamy, 2011: Anthropogenic aerosols and the weakening of the South Asian summer monsoon. Science, 334, 502-505, https://doi.org/10.1126/ science.1204994.

Booth, B. B., N. J. Dunstone, P. R. Halloran, T. Andrews, and N. Bellouin, 2012: Aerosols implicated as a prime driver of twentieth-century North Atlantic climate variability. Nature, 484, 228-232, https://doi.org/10.1038/nature10946.

Boucher, O., 2015: Atmospheric Aerosols: Properties and Climate Impacts. Springer, $311 \mathrm{pp}$.

Bretherton, C. S., and S. Park, 2009: A new moist turbulence parameterization in the Community Atmosphere Model. J. Climate, 22, 3422-3448, https://doi.org/10.1175/2008JCLI2556.1.

Cai, W., and Coauthors, 2015: ENSO and greenhouse warming. Nat. Climate Change, 5, 849-859, https://doi.org/10.1038/ nclimate2743.

Capotondi, A., and Coauthors, 2015a: Understanding ENSO diversity. Bull. Amer. Meteor. Soc., 96, 921-938, https://doi.org/ 10.1175/BAMS-D-13-00117.1.

_ , Y. Ham, A. Wittenberg, and J. Kug, 2015b: Climate model biases and El Niño Southern Oscillation (ENSO) simulation. U.S. CLIVAR Variations, No. 13, U.S. CLIVAR Office, Washington, D.C., 21-25.

Chang, C.-Y., J. C. H. Chiang, M. F. Wehner, A. R. Friedman, and R. Ruedy, 2011: Sulfate aerosol control of tropical Atlantic climate over the twentieth century. J. Climate, 24, 2540-2555, https://doi.org/10.1175/2010JCLI4065.1.

Chang, P., 1996: The role of the dynamic ocean-atmosphere interactions in the tropical seasonal cycle. J. Climate, 9, 2973-2985, https://doi.org/10.1175/1520-0442(1996)009<2973: TROTDO $>2.0 . \mathrm{CO} ; 2$.

_ - L. Ji, B. Wang, and T. Li, 1995: Interactions between the seasonal cycle and El Niño-Southern Oscillation in an intermediate coupled ocean-atmosphere model. J. Atmos. Sci., 52, 2353-2372, https://doi.org/10.1175/1520-0469(1995)052<2353: IBTSCA $>2.0 . \mathrm{CO} ; 2$.

— - — and H. Li, 1997: A decadal climate variation in the tropical Atlantic Ocean from thermodynamic air-sea interactions. Nature, 385, 516-518, https://doi.org/10.1038/ $385516 \mathrm{a} 0$

Chen, C., M. A. Cane, A. T. Wittenberg, and D. Chen, 2017: ENSO in the CMIP5 simulations: Life cycles, diversity, and responses to climate change. J. Climate, 30, 775-801, https://doi.org/ 10.1175/JCLI-D-15-0901.1.

Chiang, J. C. H., and D. J. Vimont, 2004: Analogous Pacific and Atlantic meridional modes of tropical atmosphere-ocean variability. J. Climate, 17, 4143-4158, https://doi.org/10.1175/ JCLI4953.1.

—, and A. R. Friedman, 2012: Extratropical cooling, interhemispheric thermal gradients, and tropical climate change. Annu. Rev. Earth Planet. Sci., 40, 383-412, https://doi.org/ 10.1146/annurev-earth-042711-105545.

Collins, M., 2003: Predictions of climate following volcanic eruptions. Volcanism and the Earth's Atmosphere, Geophys. Monogr., Vol. 139, Amer. Geophys. Union, 283-300, https:// doi.org/10.1029/139GM19.

DelSole, T., M. K. Tippett, and J. Shukla, 2011: A significant component of unforced multidecadal variability in the recent acceleration of global warming. J. Climate, 24, 909-926, https:// doi.org/10.1175/2010JCLI3659.1.
Dijkstra, H. A., 2006: The ENSO phenomenon: Theory and mechanisms. Adv. Geosci., 6, 3-15, https://doi.org/10.5194/ adgeo-6-3-2006.

Donohoe, A., J. Marshall, D. Ferreira, and D. McGee, 2013: The relationship between ITCZ location and cross-equatorial atmospheric heat transport: From the seasonal cycle to the last glacial maximum. J. Climate, 26, 3597-3618, https://doi.org/ 10.1175/JCLI-D-12-00467.1.

England, M. H., and Coauthors, 2014: Recent intensification of wind-driven circulation in the Pacific and the ongoing warming hiatus. Nat. Climate Change, 4, 222-227, https://doi.org/ 10.1038/nclimate2106.

Friedman, A. R., Y. T. Hwang, J. C. H. Chiang, and D. M. W. Frierson, 2013: Interhemispheric temperature asymmetry over the twentieth century and in future projections. J. Climate, 26, 5419-5433, https://doi.org/10.1175/JCLI-D-12-00525.1.

Frierson, D. M. W., and Coauthors, 2013: Contribution of ocean overturning circulation to tropical rainfall peak in the Northern Hemisphere. Nat. Geosci., 6, 940-944, https://doi.org/ 10.1038/ngeo1987.

Ghan, S. J., X. Liu, R. C. Easter, R. Zaveri, P. J. Rasch, J. H. Yoon, and B. Eaton, 2012: Toward a minimal representation of aerosols in climate models: Comparative decomposition of aerosol direct, semidirect, and indirect radiative forcing. J. Climate, 25, 6461-6476, https://doi.org/10.1175/JCLI-D-1100650.1.

Giannini, A., R. Saravanan, and P. Chang, 2003: Oceanic forcing of Sahel rainfall on interannual to interdecadal time scales. Science, 302, 1027-1030, https://doi.org/10.1126/ science.1089357.

Gill, A. E., 1980: Some simple solutions for heat-induced tropical circulation. Quart. J. Roy. Meteor. Soc., 106, 447-462, https:// doi.org/10.1002/qj.49710644905.

Green, B., and J. Marshall, 2017: Coupling of trade winds with ocean circulation damps ITCZ shifts. J. Climate, 30, 43954411, https://doi.org/10.1175/JCLI-D-16-0818.1.

,-- , and A. Donohoe, 2017: Twentieth century correlations between extratropical SST variability and ITCZ shifts. Geophys. Res. Lett., 44, 9039-9047, https://doi.org/10.1002/ 2017GL075044.

He, J., and B. J. Soden, 2015: Anthropogenic weakening of the tropical circulation: The relative roles of direct $\mathrm{CO}_{2}$ forcing and sea surface temperature change. J. Climate, 28, 8728-8742, https://doi.org/10.1175/JCLI-D-15-0205.1.

Held, I. M., and B. J. Soden, 2000: Water vapor feedback and global warming. Annu. Rev. Energy Environ., 25, 441-475, https:// doi.org/10.1146/annurev.energy.25.1.441.

Hurrell, J. W., and Coauthors, 2013: The Community Earth System Model: A framework for collaborative research. Bull. Amer. Meteor. Soc., 94, 1339-1360, https://doi.org/10.1175/BAMS-D12-00121.1.

Hwang, Y. T., D. M. W. Frierson, and S. M. Kang, 2013: Anthropogenic sulfate aerosol and the southward shift of tropical precipitation in the late 20th century. Geophys. Res. Lett., 40, 2845-2850, https://doi.org/10.1002/grl.50502.

IPCC, 2013: Climate Change 2013: The Physical Science Basis. T. F. Stocker et al., Eds., Cambridge University Press, 1535 pp.

Kosaka, Y., and S. P. Xie, 2013: Recent global-warming hiatus tied to equatorial Pacific surface cooling. Nature, 501, 403-407, https://doi.org/10.1038/nature12534.

Lamarque, J.-F., and Coauthors, 2010: Historical (1850-2000) gridded anthropogenic and biomass burning emissions of reactive gases and aerosols: Methodology and application. 
Atmos. Chem. Phys., 10, 7017-7039, https://doi.org/10.5194/ acp-10-7017-2010.

Lehner, F., A. P. Schurer, G. C. Hegerl, C. Deser, and T. L. Frölicher, 2016: The importance of ENSO phase during volcanic eruptions for detection and attribution. Geophys. Res. Lett., 43, 2851-2858, https://doi.org/10.1002/2016GL067935.

L'Heureux, M. L., S. Lee, and B. Lyon, 2013: Recent multidecadal strengthening of the Walker circulation across the tropical Pacific. Nat. Climate Change, 3, 571-576, https://doi.org/ 10.1038/nclimate1840.

Lindzen, R. S., and S. Nigam, 1987: On the role of sea surface temperature gradients in forcing low-level winds and convergence in the tropics. J. Atmos. Sci., 44, 2418-2436, https://doi.org/10.1175/ 1520-0469(1987)044<2418:OTROSS >2.0.CO;2.

Liu, X., and Coauthors, 2012: Toward a minimal representation of aerosols in climate models: Description and evaluation in the Community Atmosphere Model CAM5. Geosci. Model Dev., 5, 709-739, https://doi.org/10.5194/gmd-5-7092012.

Maher, N., S. McGregor, M. H. England, and A. Sen Gupta, 2015: Effects of volcanism on tropical variability. Geophys. Res. Lett., 42, 6024-6033, https://doi.org/10.1002/2015 GL064751.

McGregor, S., A. Timmermann, M. F. Stuecker, M. H. England, M. Merrifield, F.-F. Jin, and Y. Chikamoto, 2014: Recent Walker circulation strengthening and Pacific cooling amplified by Atlantic warming. Nat. Climate Change, 4, 888-892, https:// doi.org/10.1038/nclimate2330.

McPhaden, M. J., S. E. Zebiak, and M. H. Glantz, 2006: ENSO as an integrating concept in Earth science. Science, 314, 1740 1745, https://doi.org/10.1126/science.1132588.

Morrison, H., and A. Gettelman, 2008: A new two-moment bulk stratiform cloud microphysics scheme in the Community Atmosphere Model, version 3 (CAM3). Part I: Description and numerical tests. J. Climate, 21, 3642-3659, https://doi.org/ 10.1175/2008JCLI2105.1.

Neale, R. B., J. H. Richter, and M. Jochum, 2008: The impact of convection on ENSO: From a delayed oscillator to a series of events. J. Climate, 21, 5904-5924, https://doi.org/10.1175/ 2008JCLI2244.1.

Neelin, J. D., 2010: Climate Change and Climate Modeling. Cambridge University Press, $282 \mathrm{pp}$.

— D. S. Battisti, A. C. Hirst, F.-F. Jin, Y. Wakata, T. Yamagata, and S. E. Zebiak, 1998: ENSO theory. J. Geophys. Res., 103, 14 261-14 290, https://doi.org/10.1029/97JC03424.

Nobre, P., and J. Shukla, 1996: Variations of sea surface temperature, wind stress, and rainfall over the tropical Atlantic and South America. J. Climate, 9, 2464-2479, https:// doi.org/10.1175/1520-0442(1996)009<2464:VOSSTW>2.0. $\mathrm{CO} ; 2$.

Ocko, I. B., V. Ramaswamy, and Y. Ming, 2014: Contrasting climate responses to the scattering and absorbing features of anthropogenic aerosol forcings. J. Climate, 27, 5329-5345, https://doi.org/10.1175/JCLI-D-13-00401.1.

Ohba, M., H. Shiogama, T. Yokohata, and M. Watanabe, 2013: Impact of strong tropical volcanic eruptions on ENSO simulated in a coupled GCM. J. Climate, 26, 5169-5182, https:// doi.org/10.1175/JCLI-D-12-00471.1.

Park, S., and C. S. Bretherton, 2009: The University of Washington shallow convection and moist turbulence schemes and their impact on climate simulations with the Community Atmosphere Model. J. Climate, 22, 3449-3469, https://doi.org/ 10.1175/2008JCLI2557.1.
Pohlmann, H., and Coauthors, 2013: Improved forecast skill in the tropics in the new MiKlip decadal climate predictions. Geophys. Res. Lett., 40, 5798-5802, https://doi.org/10.1002/2013GL058051.

Rotstayn, L. D., and U. Lohmann, 2002: Tropical rainfall trends and the indirect aerosol effect. J. Climate, 15, 2103-2116, https:// doi.org/10.1175/1520-0442(2002)015<2103:TRTATI >2.0.CO;2.

Schneider, T., T. Bischoff, and G. H. Haug, 2014: Migrations and dynamics of the intertropical convergence zone. Nature, $\mathbf{5 1 3}$, 45-53, https://doi.org/10.1038/nature13636.

Schwendike, J., P. Govekar, M. J. Reeder, R. Wardle, G. J. Berry, and C. Jakob, 2014: Local partitioning of the overturning circulation in the tropics and the connection to the Hadley and Walker circulations. J. Geophys. Res. Atmos., 119, 1322-1339, https://doi.org/10.1002/2013JD020742.

Shindell, D. T., A. Voulgarakis, G. Faluvegi, and G. Milly, 2012 Precipitation response to regional radiative forcing. Atmos. Chem. Phys., 12, 6969-6982, https://doi.org/10.5194/acp-126969-2012.

Smith, D. M., and Coauthors, 2016: Role of volcanic and anthropogenic aerosols in the recent global surface warming slowdown. Nat. Climate Change, 6, 936-940, https://doi.org/10.1038/ nclimate3058.

Sobel, A. H., 2007: Simple models of ensemble-averaged precipitation and surface wind, given the sea surface temperature. The Global Circulation of the Atmosphere, T. Schneider and A. H. Sobel, Eds., Princeton University Press, 219-251.

Stevens, B., and G. Feingold, 2009: Untangling aerosol effects on clouds and precipitation in a buffered system. Nature, $\mathbf{4 6 1}$, 607-613, https://doi.org/10.1038/nature08281.

Stevenson, S., B. Otto-Bliesner, J. Fasullo, and E. Brady, 2016: "El Niño like" hydroclimate responses to last millennium volcanic eruptions. J. Climate, 29, 2907-2921, https://doi.org/10.1175/ JCLI-D-15-0239.1.

Swanson, K. L., G. Sugihara, and A. A. Tsonis, 2009: Long-term natural variability and 20th century climate change. Proc. Natl. Acad. Sci. USA, 106, 16120-16123, https://doi.org/ 10.1073/pnas.0908699106.

Takahashi, C., and M. Watanabe, 2016: Pacific trade winds accelerated by aerosol forcing over the past two decades. Nat. Climate Change, 6, 768-772, https://doi.org/10.1038/nclimate2996.

Timmreck, C., H. Pohlmann, S. Illing, and C. Kadow, 2016: The impact of stratospheric volcanic aerosol on decadal-scale climate predictions. Geophys. Res. Lett., 43, 834-842, https:// doi.org/10.1002/2015GL067431.

Tokinaga, H., S.-P. Xie, C. Deser, Y. Kosaka, and Y. M. Okumura, 2012: Slowdown of the Walker circulation driven by tropical Indo-Pacific warming. Nature, 491, 439-443, https://doi.org/ 10.1038/nature11576.

Vecchi, G. A., and B. J. Soden, 2007: Global warming and the weakening of the tropical circulation. J. Climate, 20, 43164340, https://doi.org/10.1175/JCLI4258.1.

Wang, C., and J. Picaut, 2004: Understanding ENSO physics-A review. Earth's Climate: The Ocean-Atmosphere Interaction, Geophys. Monogr., Vol. 147, 21-48.

Williams, K. D., A. Jones, D. L. Roberts, C. A. Senior, and M. J. Woodage, 2001: The response of the climate system to the indirect effects of anthropogenic sulfate aerosol. Climate Dyn., 17, 845-856, https://doi.org/10.1007/s003820100150.

Wu, Z., N. E. Huang, J. M. Wallace, B. V. Smoliak, and X. Chen, 2011: On the time-varying trend in global-mean surface temperature. Climate Dyn., 37, 759-773, https://doi.org/10.1007/ s00382-011-1128-8. 
Xie, S.-P., 1995: Interaction between the annual and interannual variations in the equatorial Pacific. J. Phys. Oceanogr., 25, 1930-1941, https://doi.org/10.1175/1520-0485(1995)025<1930: IBTAAI $>2.0 . \mathrm{CO} ; 2$.

1998: Ocean-atmosphere interaction in the making of the Walker circulation and equatorial cold tongue. J. Climate, 11, 189-201, https://doi.org/10.1175/1520-0442(1998)011<0189: OAIITM $>2.0 . \mathrm{CO} ; 2$.

2004: The shape of continents, air-sea interaction, and the rising branch of the Hadley circulation. The Hadley Circula- tion: Present, Past and Future, H. F. Diaz and R. F. Bradley, Eds., Springer, 121-152.

Yu, J. Y., H. Y. Kao, and T. Lee, 2010: Subtropics-related interannual sea surface temperature variability in the central equatorial Pacific. J. Climate, 23, 2869-2884, https://doi.org/ 10.1175/2010JCLI3171.1.

Zhang, R., and Coauthors, 2013: Have aerosols caused the observed Atlantic multidecadal variability? J. Atmos. Sci., 70, 1135-1144, https://doi.org/10.1175/JAS-D-120331.1 . 